\title{
“A Happy Marriage of Convenience": Gender and German Studies in Australia
}

\author{
Alison Lewis (Melbourne)
}

In the early nineteen-nineties women's studies programmes in Australian universities found themselves under threat from a new interdisciplinary field that in the United States had been challenging women's studies' exclusive hold on questions of sex and gender since the late eighties. This field was gender studies. Existing women's studies programmes in Australia that had been established a decade earlier - either as crossdisciplinary programmes run in collaboration with the traditional departments of English, History and Politics or as autonomous centres in Arts faculties - came under increasing pressure to reinvent themselves as gender studies. In the many newly formed humanities schools that were established in the nineteen-nineties under the Dawkins higher education reforms, when the technical institutes and teaching colleges (the so-called colleges of advanced education) across the country were awarded the status of universities, similar battles were waged. Here too, feminist scholars and teachers in the disciplines of literary studies, cultural studies, history, politics and sociology were expanding the parameters of their women's studies programmes. The curious thing was that teachers in the fields of women's studies often found themselves under institutional pressure to move beyond the paradigm of gender studies as well - even before gender studies had become institutionalised. What feminists in these newer universities were being exhorted to conceptualise was a postfeminist and post-gender model of the curriculum, a model in which gender equality could be more or less assumed or taken for granted.

The rationale for this was, ostensibly, that humanities majors within the Bachelor of Arts degree already sufficiently addressed gender concerns across the curriculum. At the time there was a trend in many Australian universities towards offering area studies majors such as Asian Studies and European Studies. Gender studies, it was thought in some places, did not sit well within geographically defined majors. Many managers or heads of programmes questioned whether arts or humanities 
programmes needed autonomous women's studies or gender studies programmes or majors within the new majors at all. It was therefore not at all surprising that for administrators and managerial staff in the newer universities the debates about whether to call the field women's or gender studies seemed entirely peripheral to their main objective, which was to remodel the traditional arts and humanities curriculum from the bottom up. Their preferred strategy was to mainstream questions of gender, thereby incorporating gender into all majors and all subjects within them. This solution appeared to offer a rather neat way out of the problem of having majors with a regional focus alongside others with a more partisan or even ideological focus such as women's studies or even feminist studies. Feminists responsible for designing these majors expressed concerns that an integrated model would most likely render gender invisible. They feared moreover that the incorporation of gender into the curriculum in this way, if carried out too hastily, would spell the premature death of gender studies before it had even been introduced.

Needless to say, not all university managers driving the curriculum reform in the newer universities were successful in their attempts to block the setting up of gender studies majors. Not all managed to include gender in the curriculum simply through mainstreaming gender as a concern in each of the disciplines or area studies. In at least one northern Queensland university, staff members were successful in their bid to introduce a gender studies major, one, albeit, that was named feminist studies rather than gender studies, the choice of title being itself indicative of the political nature of the struggle involved in its establishment.

At the beginning of the nineteen-nineties the two debates outlined here - on the one hand whether to reconfigure women's studies as gender studies, and on the other hand whether the introduction of a women's studies or gender studies major in newer programmes around the country was even warranted - were fought out more or less parallel to one another across the country. What united them was the broad realisation that the umbrella term of women's studies had become too restrictive, even too prescriptive, in its focus. This was primarily because it failed to take into account the fact that feminists were not only concerned with empirical or 
historical women and their experiences, but that they were also concerned with textual representations of women and with woman as sign, emblem or symbol. Feminists - this was particularly the case in cultural and literary studies - had become increasingly interested in questions of gender symbolisation and metaphoricisation and with male and female fantasies of the feminine, which often stood in a contradictory relationship to the lives of real women. The dilemma that feminists faced at the time was how to widen the frame of reference of women's studies to include new poststructuralist directions in the field while not losing sight of the fact that women's/gender studies should still primarily be concerned with women and the feminine. A name change from women's studies to gender studies was thought the best way to reflect this paradigm shift.

At the same time, however, the exclusive focus on women was under threat from a different section of academia altogether. In Australia, women's studies had to contend with the burgeoning new field of men's studies that had taken off around the same time as a spate of publications on men and masculinity appeared, in particular Robert Connell's book Masculinities (1995) ${ }^{1}$ and Steve Biddulph's Manhood $(1995)^{2}$ and Raising Boys $(1997)^{3}$ and Tom Morton's Altered Mates (1997). ${ }^{4}$ Many feminists responded defensively to the interest in masculinity among their male colleagues, often regarding it in cynical terms, either as an example of men encroaching on women's territory, or as an instance of male opportunism. They feared that women's studies might be hijacked within universities by young male scholars who by 'colonising' gender might turn gender studies yet another male-dominated discipline or field. As it turned out, these fears proved to be largely unfounded, and gender studies is still today a female-centred and women-led interdisciplinary area in Australian universities. The problem in some sections of the humanities in the nineteen-nineties was not that of men colonising niche areas that

\footnotetext{
${ }^{1}$ R.W. Connell: Masculinities. St. Leonards: Allen \& Unwin 1995.

${ }^{2}$ Steve Biddulph: Manhood: An Action Plan for Changing Men's Lives. Sydney: Finch 1995.

${ }^{3}$ Steve Biddulph: Raising Boys: Why Boys are Different, and how to Help them Become Happy and Well-balanced Men. Sydney: Finch 1997.

${ }^{4}$ Tom Morton: Altered Mates: The Man Question. St. Leonards: Allen \& Unwin 1997.
} 
women had carved out for themseives; the problem in some of the smaller disciplines was quite a different one.

For feminists firmly embedded in the 'safe-houses' of language departments across academia - as sympathetic as they were to the political minefields that their contemporaries were attempting to negotiate - the debates about whether to introduce discrete teaching and research gender studies programmes seemed far removed from the sorts of institutional and disciplinary pressures they were facing. Throughout the nineteeneighties feminists in larger language departments, which had a greater range of optional subjects on offer, were relatively free to offer the occasional specialist subject on women's writing. They were even joined in a few universities by sympathetic male researchers who taught women's writing courses or who were willing to teach feminist texts collaboratively with their female colleagues. This freedom was, however, only ever relatively small, since feminists in language departments have never been in the position of offering anything more than, at most, a single subject or unit dedicated to women's writing or to feminist theory within a language major.

The mid-nineteen-nineties did, nonetheless, force new forms of engagement with questions of gender and sex in German and German Studies departments in Australia as it did in other parts of the humanities, even if for a slightly different set of reasons. The two institutional pushes to effect a paradigm shift to gender and to mainstream gender across the curriculum, elicited a different response from language departments mainly because foreign language departments were facing their own specific set of institutional challenges.

As funding was cut from many German departments in the early nineteen-nineties many women's writing subjects fell victim to pressure from above to rationalise class size and to reduce the number of subject offerings with small enrolments. Dedicated women's studies subjects often had trouble justifying their existence, especially in light of staff cuts in the mid-nineteen-nineties and the radical downsizing of German departments that was the fate, almost without exception, of every German 
department across the country. When departments were only in the position of offering one literature or culture subject per level per semester, rather than a choice of subjects, feminists resorted to creative solutions. Most responded to the challenge of rationalisation by endeavouring to ensure that, at the very least, women writers were represented on the syllabus in adequate numbers. That is, feminist Germanistics effectively opted to mainstream gender and feminist themes across the curriculum, thus resorting to the strategy of mainstreaming, not by virtue of choice but by necessity.

A discipline as small as German Studies had to contend with a different set of problems to the ones faced by English and History departments, ones that were only partly related to the question of whether to use the designation women, feminist or gender. In departments of German that were staffed by one or two people, issues of gender parity became in part a staffing matter and, hence, one governed by institutional recruitment policy. Since staff members in downsized departments had to assume far more functions than ever before, they were rarely appointed solely on the basis of having gender as a research and teaching area. Jobs were rarely advertised in the area of gender or women's studies. Women could be appointed to positions however on the basis of their gender in order to ensure gender parity within a department. As a result, it was left up to the individual staff member's preference whether s/he chose to include gender topics or women writers on the syllabus, or whether she researched gender topics at all. If a feminist was in charge of designing subjects and courses then she was at liberty to include as many women in her subjects as she thought conscionable. Where men were responsible for the design of the curriculum, the inclusion of gender and women's texts could be pretty much an ad hoc affair. With the pressures to rationalise subject offerings and the reduction of staff, gender could easily be sidelined in the post-Dawkins years.

Where departments are large enough to offer optional subjects, women's literature courses will perhaps always have their place, but for small to medium-sized language departments, the goal of mainstreaming, which once used to be seen as a remote possibility, has come about 
sooner than expected, and more by default than by design. German Studies departments in Australia have little option but to mainstream gender, and the paradigm of gender studies is arguably a more appropriate vehicle to achieve this. When whole programmes are run by two to three full-time staff members, who may be male, feminist Germanists are reliant on enlisting male colleagues as allies, if the gender imbalance in the syllabus is ever to be redressed and the discipline is to be reproduced in gender-inclusive ways. Indeed, it could be argued that feminists in German Studies cannot afford to do without sympathetic male scholars who have recognised the importance of including gender (as well as categories such as race, sexuality and ethnicity) in their teaching. In the context of the downsizing of German departments in Australia, the mainstreaming of gender in teaching and, to a lesser extent, in research, has been an important means of survival. If gender is not to be marginalised, it is essential that German departments adopt as broad and pluralistic a view of gender studies as possible.

There are, however, a number of problems with moving out of the shadows of the margins of women's studies into the mainstream too soon. As Sigrid Weigel pointed out in 1995 in relation to the German context, there is the danger that gender studies become seen as "die Überwindung einer vorausgegangenen Phase." She rightly points out that the move to gender could be misinterpreted as the overcoming of a politicised feminist phase of consciousness-raising about gender concerns. If the interrogation of gender becomes added to a lengthy list of binary oppositions to be deconstructed, as one category to be investigated among a range of others, gender runs the risk of being sidelined: at best, it lends itself to a guest lecture from a friendly female colleague, at worst, it does not rate a mention at all.

In addition, there is the danger of gender relativism. If masculinity is factored into the equation, then gender can cease, for some colleagues at least, to matter as a term altogether. It is easy for gender to become

\footnotetext{
${ }^{5}$ Sigrid Weigel: "Geschlechterdifferenz und Literaturwissenschaft." In: Literaturwissenschaft: Ein Grundkurs. H. Brackert, and J. Stüickrath (eds.), Hamburg: Rowohlt 1992.
} 
invisible, especially if it is erroneously seen as affecting both sexes in more or less equal but different measure. The goal of gender equality is frequently conflated with achieving gender sameness and with the erasure or neutralisation of gender difference.

By the same token, there are a number of gains to be made by adopting gender as a dominant category for analysis in cultural studies, literature and linguistic subjects at the undergraduate and postgraduate level. It is not that gender necessarily includes the study of masculinity and men in its purview that makes it ultimately more attractive as a methodology; it is arguably because the study of gender is less concerned with empiricism and the experiences of women that ultimately makes it more useful as a tool of analysis. This is particularly the case in literary studies, which deal with representations of the feminine and masculine and with gender perceptions and projections rather than with real historical women. A shift towards gender studies should not mean, however, that we as teachers and supervisors of students abandon a feminist commitment to achieving parity and equality. In Australia gender studies is generally perceived as more value-neutral than women's studies, since it does not presuppose an active engagement with feminist politics. It is nonetheless still premised on feminist insights that are the outcome of feminist politics and years of feminist lobbying.

The paradigm shift from sex to gender has meant that the old sex/gender distinction or the "sex/gender system" initially proposed by Gayle Rubin in 1975 in her famous essay on "Traffic in Women" has been deconstructed. ${ }^{6}$ Throughout the 1970s and 1980s feminists in Australia, as elsewhere in the world, were at pains to distinguish between the social and cultural construct of gender, and sex, which was used to refer to women's nature or biology, which was seen as more or less fixed. But as latter-day feminists, and more recently queer theorists, have subsequently pointed out, sex itself is not a biological given but is a dis-

\footnotetext{
${ }^{6}$ Gayle Rubin: "The Traffic of Women: Notes on the Political Economy of Sex." In: Toward an Anthropology of Women. Rayna R. Reiter, ed. New York: Monthly Review Press 1975, 157-210.
} 
cursive construct as well. Sex is not fixed or organised only in binary categories. As Butler said famously in Gender Trouble: "If the immutable character of sex is contested, perhaps this construct called 'sex' is as culturally contested as gender; indeed, perhaps it was always already gender, with the consequence that the distinction between sex and gender turns out to be no distinction at all." Sex and gender are, according to this view, the "effects of specific formations of power," they are discursive effects of specific regimes of power that produce "bodily beings." To quote Butler again: "Sex is always produced as a reiteration of hegemonic norms. This productive reiteration can be read as a kind of performativity [...] that appears to produce that which it names, to enact its own referent, to name and to do, to name and to make."8 Butler's approach, inspired as it is by Michel Foucault's work on the discursivity of the body and sexuality allows for notions of sexuality, sexual preference as well as gender identifications to come into play, as well as for new categories of analysis such as gender identity, gendered bodies, gender as performance, and gender subversion (such as transgression, mimicry and masquerade, passing, crossing and queering and other forms of "rematerialisation" and "rearticulation" of gender norms). The interpretative tools developed by queer theory, which have themselves some degree of overlap with the neighbouring fields of postcolonial studies and subaltern studies, have much potential for German Studies.

Adopting a gender studies approach does not mean abandoning the work of rediscovering forgotten female voices in literary history, nor does it mean jettisoning the valuable work already begun of subjecting male writers to feminist critiques. The two strands of feminist enquiry identified by Elaine Showalter in 1979 and 1981, feminist critique and gynocritics, are still valid avenues of scholarly endeavour in Germanistik in Germany and in German Studies outside Germany. While feminist critique was concerned with women as readers of men's books, gynocritics was about women as writers of their own books. The former focused on a critique of female stereotypes and roles in mostly canonical texts by men;

\footnotetext{
${ }^{7}$ Judith Butler: Bodies That Matter. London: Routledge 1993, 107.

${ }^{8}$ Butler, 107.
} 
the latter suspended the feminist "hermeneutics of suspicion" and adopted an openly partisan approach to women's texts, seeking to uncover a buried female culture and listen to the silenced voices of forgotten women writers. ${ }^{9}$ Both approaches still co-exist happily in German Studies in Australia today and both have spilled out over their methodological borders of the early 1980s, mainly through cross-fertilisation with gender studies and other disciplines such as psychoanalysis and discourse analysis.

Feminist critique has been enriched by a move away from the study of stereotypes, images of women and gender roles in German literature, to a more differentiated discussion of contexts or to what Sigrid Weigel has called "die Frage nach dem Ursprung bzw. den Bedingungen der Möglichkeit bestimmer Weiblichkeitsentwürfe."10 This has enabled researchers to explore more widely the various relationships between gender difference and transnational categories of the Enlightenment, modernity, postmodernity, colonialism and postcoloniality. These shifts have brought with them a focus on "der Ort des Weiblichen," on "Weiblichkeitsmythen" and the "Ordnung der Geschlechter," on primal scenes of gender dramaturgy and of gender phantasma, on male fantasies (following on from Klaus Theweleit's Männerphantasien $)^{11}$ and imagined femininity and masculinity (inspired by Silvia Bovenschen's Die imaginierte Weiblichkeit $)^{12}$ as well as with feminine myths and legends underpinning cultural anthropology. ${ }^{13}$

With the end of the Cold War and the unification of Germany a fertile new field of enquiry, which has gender as its key term, has emerged that is ripe for the harvesting for Germanists. Unification has spawned a new

\footnotetext{
${ }^{9}$ Elaine Showalter: "Towards a Feminist Poetics." In: Women Writing and Writing About Women. Mary Jacobus (ed.), London: Croom Helm 1979, 22-41 and Elaine Showalter: "Feminist Criticism in the Wilderness," Critical Inquiry 8.1 (1981): 179-205.

${ }^{10}$ Sigrid Weigel: "Geschlechterdifferenz und Literaturwissenschaft." In: Literaturwissenschaft: ein Grundkurs. H. Brackert and J. Stückrath (eds.), Reinbek bei Hamburg: Rowohlt $1992,692$.

${ }^{11}$ Klaus Theweleit: Männerphantasien. Frankfurt am Main: Piper 2000.

${ }^{12}$ Silvia Bovenschen: Die imaginierte Weiblichkeit. Frankfurt am Main: Suhrkamp 1979.

${ }^{13}$ Sigrid Weigel: "Geschlechterdifferenz und Literaturwissenschaft," 693.
} 
corpus of literary texts - often referred to as Wendeliteratur - but which I shall refer to as post-unification literature. German unification has not only left its mark on literary texts that deal explicitly with the historical and political events of unification, such as books about the Monday demonstrations and the fall of the Berlin Wall. The effects of unification can be seen in a wide range of literary works that deal in broad terms with the many problems and opportunities of transition from communism to capitalism. The field of post-unification fiction is, for instance, characterised by works that interrogate national and personal identity and belonging, the loss of Heimat, nostalgia, East-West differences and asymmetries that have arisen since the collapse of the GDR. The investigation of this rapidly growing corpus of literature, it will be argued here, requires an interdisciplinary approach that borrows from a number of related but discrete disciplines, from psychoanalysis, literary theory, narratology, history, politics, social theory and sociology as well as intertextuality. It lends itself moreover to an approach that allows the investigator to draw on the depth of feminist research in each of these disciplines.

The massive sea changes that took place with the unification of Germany and the collapse of Eastern European communism had a profound impact on the everyday lives of men and women from the former East Germany. Sociologists, in particular Ulrich Beck and Elisabeth BeckGernsheim, have explained the transition in terms of "sudden surges in individualisation." ${ }^{14}$ Individualisation, modernisation as well as the transition from a socialist to a capitalist model of democracy inevitably forced a rethinking of gender roles and expectations. In many ways, unification effectively rewrote the scripts for femininity and masculinity, requiring East German men and women to reconceptualise their life stories and replot their life trajectories from the bottom up. As Beck and BeckGernsheim have pointed out, individualisation, as one aspect of the modernisation process, has historically always affected the sexes in different measure. Gender asymmetry has, they argue, always been written into the modernisation project. Men and women share for this reason

\footnotetext{
${ }^{14}$ Ulrich Beck and Elisabeth Beck-Gernsheim: Das ganz normale Chaos der Liebe. Frankfurt am Main: Suhrkamp 1990, 9.
} 
fundamentally different "gender fates" ("Geschlechtsschicksale") in modernity and postmodernity. ${ }^{15}$ This also applies to the new Germany.

One of the central factors affecting gender relations in post-unification society was, to use Anthony Giddens' term, the "transformation of intimacy."16 The sort of "individualised society" to which East Germans were exposed in a very short space of time presented unprecedented challenges to "intimacy," that is, to the spheres of love, marriage and the family, in particular to spheres that have traditionally been women's domains. Unification profoundly altered the shape and trajectory of socialist biographies, which has had major consequences for the way that people lead their private lives. Personal histories of GDR citizens were suddenly removed from their safe and familiar socialist contexts and stripped of their ideological and political underpinnings. With the acceleration of individualisation processes through contact with what Zygmunt Bauman has called "liquid modernity," there were immense pressures on socialist biography to turn itself into Western "choice biography." "17 Yet the Western phenomenon of "choice biography" was itself a paradoxical affair. On the one hand, GDR citizens were confronted with circumstances in the new Germany, especially in the workforce, over which they had little control. For instance women, who had taken state-subsidised child-care for granted and built their careers around the compatibility of work and a family, often faced not more choice but less. While the domain of work was generally an area in which East Germans had very little choice in deciding their fates, in most other parts of daily life they were presented with almost too much choice and a daunting range of opportunities and freedoms.

The changes in lifestyle occurring in Eastern Germany in the first decade of German unification have produced new forms of gender difference that have led to a repositioning of gender, of gender roles, gender identity and norms. These are in many ways reminiscent of what Beck

\footnotetext{
${ }^{15}$ Beck and Beck-Gernsheim, 40.

${ }^{16}$ Anthony Giddens: The Transformation of Intimacy: Sexuality, Love and Eroticism. Cambridge: Cambridge UP 1992.

${ }^{17}$ Zygmunt Bauman: Liquid Modernity. Cambridge: Polity 2000.
} 
and Beck-Gernsheim have called a modern "Geschlechter-IndianerLiebes-Kampf-Spiel."18 They see this struggle between the sexes as being due to the incompatibility between the demands of love and marriage on the one hand and the demands of the labour force on the other. Gender has become implicated in new forms of struggle, struggles that Beck and Beck-Gernsheim call the "Klassenkonflikt, der nach dem Klassenkonflikt kommt," which is translated in the English version of Das ganz normale Chaos der Liebe as the "status struggle." emergence of newer systems of difference, complicating and compounding other systems of difference such as the divide between East and West, between the employed and the unemployed, the affluent and the impoverished. While both sexes have had very little choice but to engage in the status struggle and all that this implies, unification has affected men and women in different ways. Both sexes have for instance had to participate in the race to acquire forms of status, wealth, signs of influence and prestige - what Pierre Bourdieu has called social, symbolic and cultural capital. $^{20}$ This race affects the sexes in unequal measure since men and women have quite different capacities to access and acquire capital.

It has been argued by feminist sociologists such as Barbara Einhorn that the changes brought about for gender relations by the collapse of Eastern and Central European communism represent essentially a "reterritorialisation" of femininity and masculinity that heralds a return to a "nineteenth century model of domesticated women with no claim to citizenship rights in society."21 In her study of the impact of the dismantling of communist regimes in Europe from the early nineteennineties, Cinderella Goes to Market, Einhorn is pessimistic about the gains to be had from the end of communism and predicts a gender

\footnotetext{
${ }^{18}$ Beck and Beck-Gernsheim: Das ganz normale Chaos der Liebe. 14-15.

${ }^{19}$ Ulrich Beck and Elisabeth Beck-Gernsheim: The Normal Chaos of Love. transl. Mark Ritter and Jane Wiebel. Oxford: Polity Press 1995, 2.

${ }^{20}$ Pierre Bourdieu: The Field of Cultural Production: Essays on Art and Literature. Ed. Randal Johnson. Cambridge: Cambridge UP 1993.

${ }^{21}$ Barbara Einhorn: Cinderella Goes to Market: Citizenship, Gender and Women's Movements in East Central Europe. London: Verso 1993, 216.
} 
backlash of lasting proportions. ${ }^{22}$ Instead of greater political participation and "substantive" rather than tokenistic equality, she argues, East German women faced the prospect of the loss of older rights that had been automatically guaranteed under state socialism.

According to Einhorn, unification marked a sudden return to older, outmoded forms of gender relations in Eastern and Central Europe and saw a resurgence of superseded modes of the reproduction of gender. ${ }^{23}$ Women had to bear the brunt of most of the economic changes, which has meant that in a whole range of areas women have been the main "losers of unification."24 As Hanna Behrend has pointed out in a study of East German women's attitudes to the changes five years after the Wende, onethird of East German women have coped badly with the new conditions and consider themselves to be losers. ${ }^{25}$ They were hardest hit by economic restructuring and the group most affected by mass unemployment. They also had to contend with the loss of social privileges such as the right to work and automatic access to state-subsidised childcare. While many women welcomed unification as a chance to choose between staying at home and entering the workforce, many women have not been free to avail themselves of this choice. In addition to this, many women have had to put their career aspirations to one side in order to enhance their husband's employment opportunities.

According to Beck and Beck-Gernsheim, the pressures of the labour market are such that it is becoming increasingly difficult to combine two

\footnotetext{
${ }^{22}$ After the initial euphoria among women's groups and movements in East and West late in 1989 had faded, questions of women's emancipation receded into the background. The velvet revolution failed to transform itself into a second feminist revolution, as many groups had hoped, and feminist groups failed to play a significant role either during or after unification. The time of spontaneous democratic and civil rights' movements passed quickly as the stark realities of unification struck home. Einhorn's pessimism is best understood in this context. (Barbara Einhorn, Cinderella Goes to Market).

${ }^{23}$ Barbara Einhorn: Cinderella Goes to Market, lff.

${ }^{24}$ Jenny Niederstadt: "Vereinigung zu Lasten der ostdeutschen Frauen." In: Kolonisierung der DDR. Wolfgang Dümcke and Fritz Vilmar (eds.), Münster: Agenda Verlag 1996, 255275.

${ }^{25}$ Hanna Behrend: "East German Women Five Years after the Wende." In: New Frontiers in Women's Studies: Knowledge, Identity and Nationalism. Mary Maynard and June Purvis (eds.), London: Taylor \& Francis 1996, 222-23.
} 
"labour market biographies," that is, it is harder for both partners in marriage to work outside the home. Traditionally, in West German society, it has been women who have had to suffer most from the systemic contradictions in modern industrialised societies between family and work. ${ }^{26}$ In West Germany the ideal accompaniment to a masculine "labour market biography" has always been the life of a housewife. ${ }^{27}$ In East Germany, the life of a housewife was not an option favoured by the state and by East German women. On the contrary, women were expected and encouraged to work. ${ }^{28}$ At the same time, they were expected to be mothers and wives. The socialist family was based on a model that enabled, at least in theory, two labour market biographies to co-exist in tandem. Official socialist ideology required that women perform both the roles of worker in public and mother and lover in private. What the ideal socialist family did not foresee was that women might want to be delivered from their traditional roles as mothers and heads of the household. Instead, women were forced to struggle with the "double burden" of home and work and to seek creative ways of negotiating the multiple contradictions of their public and private lives. ${ }^{29}$

Sociological research has painted a fairly bleak picture of women's prospects in the new Germany, underlining the fundamental ambivalence of the process and outcomes of unification for women. However, not all women have been the losers of the unification process and, in 1993, 80 per cent of women considered themselves to be "more or less" satisfied with the outcomes of unification. The women who are optimistic about their prospects are under 40 years of age, single or divorced or in employment that guarantees them a high degree of job satisfaction. ${ }^{30}$ For a few

\footnotetext{
${ }^{26}$ Ulrich Beck and Elisabeth Beck-Gernsheim: Das ganz normale Chaos der Liebe, 15.

${ }^{27}$ Ulrich Beck and Elisabeth Beck-Gernsheim: Das ganz normale Chaos der Liebe, 15.

28 Affirmative action programmes and the ready availability of crèches and kindergarten places ensured that over $90 \%$ of women of working age were in full-time employment.

${ }^{29}$ Hanna Behrend argues that the Wende has not freed women from the "double burden", mainly because women in the West still carry the chief burden of family care. By far the greater problem is the loss of employment opportunities, redundancies and early retirement. See Hanna Behrend: "East German Women Five Years after the Wende," 228.

${ }^{30}$ Behrend: "East German Women Five Years after the Wende," 223.
} 
groups of women, unification has provided more opportunities, greater choice and more freedom.

The general lack of agreement among sociologists and political scientists, indeed among men and women, about the outcomes of German unification, becomes important when we apply the findings of empirical studies to literary texts. ${ }^{31}$ If our objects of analysis are literary representations of the effects of unification, we need to carefully consider how we apply these sociological insights to textual interpretation. What methods will we use, for instance, when we are dealing with works of the imagination that do not merely reflect the social changes in realist modes of representation? Does a reliance on sociology, albeit feminist sociology, mean that we end up treating fictional characters as empirical men and women whose historical and social experiences we want to reconstruct? Or does approaching this topic with the tools of gender studies instead open up new avenues of enquiry?

It can be argued that while an engagement with unification fiction may stem from a concern with the historical experiences of empirical women, and indeed may invoke our sympathy for women's loss of rights, what we are dealing with are issues of representation, that is, we are interested in literary texts that we can evaluate with the help of literary codes. This means that we are not only concerned with empirical women as the losers of unification but more generally with cultural images and emblems of the feminine and masculine and the manifold ways in which a sense of gender crisis is inscribed in literary texts. It means moreover that we are interested in the specific ways that socialist gender relations are being renegotiated in unified Germany and the means in which these gender relations are articulated in literary texts. Literature, it can be argued, can offer us answers, for instance, to the question of whether the

\footnotetext{
${ }^{31}$ For two quite differing views on the outcomes of unification see Hanna Behrend, "East German Women Five Years after the Wende" and Laurence McFalls who argues after conducting a survey in 1997/98 that Eastern Germans have successfully 'arrived' and embraced the conflicting values of a late modern capitalist society." He declares that there is convincing evidence that the process of political cultural transition has come to a close. See Laurence McFalls: "Eastern Germany Transformed: From Postcommunist to Late Capitalist Political Culture." German Politics and Society 17: 2 (1999), 9.
} 
sexes have different relationships to freedom and democracy, of whether women express more or less nostalgia for the socialist past than men, and whether one sex is the upholder of core East German values rather than the other, whether one sex is more or less objectified, one more or less colonised by Western consumerist society than the other.

Literary narratives about unification, it can be argued, have their own stories to tell about the transition from communism to democracy and the transformation of intimacy, and hence they have their own histories of unification. These stories have their own generic logic that is not necessarily congruent with the narratives of sociologists and political scientists. If it holds true, as Zygmunt Bauman has suggested, "that the stories told of lives interfere with the lives lived before the lives have been lived to be told, ${ }^{32}$ then the stories literature tells are of vital importance for the way unification is ultimately lived.

For the remainder of this paper, I will outline some research questions that can be applied to post-unification fiction and conclude by providing some examples of texts for analysis. Most literary works published in the immediate years after German unification, particularly those by East German writers, deal in some way or other with the question of biographical continuity and rupture, whether they address the topic of the Wende directly or not. There are a wide range of "biographical solutions" to social change in evidence in these works and an equally wide variety of "gender fates" that are mapped. One popular way that the impact of the transition to western-style democracy on individuals' lives is explored is via the love narrative or the romance.

In a number of works by the generation of German writers that were adolescents during the Third Reich the themes of love figure prominently. Novels such as Christa Wolf's Medea (1996), ${ }^{33}$ Martin Walser's Die Verteidigung einer Kindheit (1991) ${ }^{34}$ and Günter Grass's Unkenrufe (1992), ${ }^{35}$

\footnotetext{
${ }^{32}$ Zygmunt Bauman: The Individualized Society. Cambridge: Polity 2000, 7.

${ }^{33}$ Christa Wolf: Medea. Munich: dtv 1996.

${ }^{34}$ Martin Walser: Die Verteidigung einer Kindheit. Frankfurt am Main:Suhrkamp, 1991.

${ }^{35}$ Günter Grass: Unkenrufe. Frankfurt am Main: Luchterhand 1992.
} 
to name but a few, all incorporate elements of the romance or the family drama to explore the legacy of the communist past and the problems of transition from communism to capitalism. For this generation, the personal dramas of the private spheres of love and the family, while never absent from their earlier works, were overshadowed by the larger historical and political dramas of the Cold War and fascism. ${ }^{36}$

One obvious reason for the popularity of the romance narrative stems from the fact that unification has frequently been cast in terms of a marriage or a wedding. ${ }^{37}$ At the time optimists such as Willy Brandt spoke famously in terms of a happy union between two halves of a nation that could now "grow together" whereas pessimists tended on the whole to regard it as a "difficult marriage" between partners that have little in common. It comes as no surprise therefore that in the world of fiction, love and love stories of all kinds - along with the memoir, diary and the childhood novel - have dominated the literary field since 1989. The preoccupation with these themes is not confined to one group of writers from one or the other Germany, nor is it exclusive to one generation of author.

It is among the middle generation of writers - that is to say among the authors born roughly between 1940 and 1955 - that the number of love stories is most in evidence. For this generation, broken marriages and homes, affairs, divorces and separations are popular iconographic means

\footnotetext{
${ }^{36}$ Notable exceptions to this are Martin Walser's spy novel Dorle und Wolf. Frankfurt am Main: Suhrkamp 1987 and Christa Wolf's classical Cold War tale of divided love, Der geteilte Himmel. Munich: dtv 1963, that is played out against the backdrop of the building of the Berlin Wall.

${ }^{37}$ Susan Morrison: "The Feminization of the German Democratic Republic in Political Cartoons 1989-90." Journal of Popular Culture 25.4 (1992): 35; Ingrid Sharpe: "Male Privilege and Female Virtue: Gendered Representations of the Two Germanys." New German Studies 18.1/2 (1994): 87-106; Conrad Jarausch: The Rush to German Unity. Oxford, New York: Oxford UP 1994; Beate G. Gilliar: The Rhetoric of (Re)Unification: Constructing Identity through East and West German Newspapers. New York, Washington, Bern, Frankfurt am Main, Berlin, Vienna, Paris: Lang 1996; Stephen Brockmann: Literature and German Reunification. Cambridge: Cambridge UP 1999; Alison Lewis: "Unity Begins Together': Analyzing the Trauma of German Unification." New German Critique 64 (1995): 135-59; Cheryl Dueck: "Gendered Germanies: The Fetters of a Metaphorical Marriage." German Life and Letters 54:4 (2001): 366-376.
} 
of representing breaks in biographies and more generally of figuring the personal cost of unification and social upheaval. What is especially startling about these stories is the number of love relationships and marital conflicts that are inextricably linked, either through plot or on a metaphorical level, to the loss of state sovereignty for East Germany. Change not only affects East-East German marriages; it has profound effects on East-West German affairs and marriages, on homosexual affairs and intercultural and interethnic romances. Even the scandalous intergenerational love story between a young boy and a concentration camp warden in Bernhard Schlink's international best-selling novel Der Vorleser (1995) ${ }^{38}$ suggests that unification has lifted taboos about love and romance.

What is striking about many of these narratives is that men and women manage the transition from a communist society to a capitalist one in asymmetrical ways. There are a number of instances of fictional women from the East who abandon the safe haven of the family for the more risky shores of other forms of love: either with a Westerner or with the same sex, such as the narrator's mother in Reinhard Jirgl's Die atlantische Mauer (2000). ${ }^{39}$ There are other instances of fictional women who ruthlessly tear up their roots, leaving husband and children behind them, to seek out new ways of living and loving such as in Monika Maron's Animal Triste (1996). ${ }^{40}$ By the same token, in some books it seems to be the men who leave the safety of the marital home to test their fortunes in the West, such as the husband in Brigitte Burmeister's Unter dem Namen Norma (1994). ${ }^{41}$

In a number of books, the fall of the Wall has provided female protagonists from the GDR with new opportunities for self-fulfillment and self-discovery, one of which is - apart from the chance to travel - the chance to exercise freedom of choice in the selection of a partner (as in Jirgl's Die atlantische Mauer) or, simply, in the freedom to fall

\footnotetext{
${ }^{38}$ Bernhard Schlink: Der Vorleser. Diogenes: Zürich 1995.

${ }^{39}$ Reinhard Jirgl: Die atlantische Mauer. Munich, Wien: Hanser 2000.

${ }^{40}$ Monika Maron: Animal Triste. Frankfurt am Main: Fischer 1996.

${ }^{41}$ Brigitte Burmeister: Unter dem Namen Norma. Stuttgart: Klett-Cotta 1994.
} 
unconditionally in love and to "live one's life as a love story" (in Maron's Animal Triste). Similarly, the motif of the intercultural, inter-German or inter-ethnic marriage or romance affords writers a means to explore the openings for reconciliation and atonement brought about by unification (see Günter Grass` 1992 novel Unkenrufe about German-Polish reconciliation).

While the numbers of fictional women who seize unification as an opportunity to leave the family home or marriage are plentiful, there are just as many instances of women's continued entrapment. In Birgit Vanderbeke's Das Muschelessen (1990) ${ }^{42}$ and Burmeister's Unter dem Namen Norma, for example, the move to the West provides the impetus for a return to older modes of gender reproduction and for the revival of traditional bourgeois gender roles. While the men in these novels are busily taking advantage of the whole gamut of self-realisation strategies that the West has to offer, the women find themselves far less in control of their destinies.

The vehicle of the love story allows many women writers to articulate a sense of disaffection with the new social order. Both Maron in Animal Triste and Irina Liebmann in In Berlin $(1994)^{43}$ base their novels around an East-West love affair between an East German woman and a West German man, using the trope of the end of an affair to vent their dissatisfaction with unification. Similarly, the darker other side of love in a post-communist world finds its expression in works by male and female authors in narratives about dysfunctional marriages (Christoph Hein's Willenbrock ${ }^{44}$ ), adultery and suicide (Dieter Wellershoff's Der Liebeswunsch $^{45}$ ), extra-marital affairs (Sigrid Damm's Ich bin nicht Ottilie ${ }^{46}$ ),

\footnotetext{
${ }^{42}$ Birgit Vanderbeke: Das Muschelessen. Frankfurt am Main: Fischer 1990.

${ }^{43}$ Irina Liebmann: In Berlin. Cologne: Kiepenheuer \& Witsch 1994.

${ }^{44}$ Christoph Hein: Willenbrock. Frankfurt am Main: Suhrkamp 2000.

${ }^{45}$ Dieter Wellershoff: Der Liebeswunsch. Cologne: Kiepenheuer \& Witsch 2000.

${ }^{46}$ Sigrid Damm: Ich bin nicht Ottilie. Frankfurt am Main: Insel 1992.
} 
violence and abuse (Norbert Niemann's Die Schule der Gewalt ${ }^{47}$ ) and occasionally rape (Ingo Schulze's Simple Storys). ${ }^{48}$

A significant number of male writers have also turned their attention to the themes of romance and love in the nineteen-nineties. Several West German writers explore issues of betrayal and relationship breakdown in the broader context of the unification of the two Germanies. This is particularly in evidence in works by the sixty-eight generation such as in Peter Schneider's Paarungen (1992) ${ }^{49}$ and Eduards Heimkehr (1999) ${ }^{50}$ and also in some of the stories in Bernhard Schlink's Liebesfluchten (2000). ${ }^{51}$ But more generally too, love as a theme has been taken up by male and female writers from all generations as well as from East and West.

Gender difference is, it can therefore be argued in summary, "eine der wirkungsvollsten bedeutungskonstituierenden Differenzen," and the field of unification literature is no exception. ${ }^{52}$ While gender itself can be a central category for analysis in unification literature, the breadth of approaches within the wider framework of unification studies suggests that we need not limit ourselves to literary approaches to interpreting these texts. The key issue of rapid social change and biographical continuity und rupture in many of these books necessitates that we draw on the interdisciplinary work of sociology and feminist sociology in relation to gender, the family and marriage as well as on the sociological theories of "risk biography" and individualisation. The broad approach advocated here is one that requires us to conceptualise a framework of analysis that takes into consideration the social and political context of unification, drawing on insights from social history, political science, feminist sociology and ethnography. This does not mean, however, that we ought to read unification literature purely in sociological terms. However, in taking

\footnotetext{
${ }^{47}$ Norbert Niemann: Schule der Gewalt. Munich: Carl Hanser 2001.

${ }^{48}$ Ingo Schulze: Simple Storys: Ein Roman aus der ostdeutschen Provinz. Berlin: Berlin Verlag 1998.

${ }^{49}$ Peter Schneider: Paarungen. Berlin: Rowohlt 1992.

${ }^{50}$ Peter Schneider: Eduards Heimkehr. Berlin: Rowohlt 1999.

${ }^{51}$ Bernhard Schlink: Liebesfluchten. Zürich: Diogenes 2000.

${ }^{52}$ Sigrid Weigel: "Geschlechterdifferenz und Literaturwissenschaft," 695.
} 
the insights from sociology as our first frame of reference, and perhaps as our widest frame, we are still able to deploy a wide and possibly even eclectic range of interdisciplinary approaches from areas as far afield as psychoanalysis, anthropology, deconstruction, queer theory, philosophy, social theory to narrative and literary theory.

The field of unification literary studies becomes infinitely richer when the plurality of interdisciplinary methods from gender studies is brought to bear on the equally wide range of methods from unification and transition studies. While there is a danger that the political edge of a feminist critique is lost by moving too quickly to the paradigm of gender studies - and it could be argued that with unification there is a stronger need than before to revive practices of feminist critique - there are equally many significant gains to be made in other areas. By combining gender studies with other interdisciplinary fields gender can be placed back onto centre stage. By having faith in the plurality of approaches and in the power of persuasion of feminist critiques of gender as a power relationship, and by making an engagement with gender a key issue, the marginalisation of gender concerns can be avoided. What is lost on the hurdygurdy of feminist studies can be regained on the merry-go-rounds of gender studies. 